\title{
Factors Affecting Purchase Intention of Customers to Shop at Hypermarkets
}

\author{
S M Sohel Rana
}

PhD candidate, School of Business Innovation and Technopreneurship. University Malaysia Perlis

Email: smsohelrana@ymail.com

\author{
Abdullah Osman \\ Senior Lecturer, School of Business Innovation and Technopreneurship. University Malaysia Perlis \\ Email: abdullahosman@unimap.edu.my

\section{Yusuf Haji Othman}

Kolej Universiti Insaniah. Alor Setar. Kedah

Email: yusufhajiothman@yahoo.com

Doi:10.5901/mjss.2015.v6n3p429

\begin{abstract}
Customers' purchase intention represents their desire to buy products from a particular shop. Product quality, brand image, socioeconomic condition and social influence have been considered in this study as the key factors affecting purchase intention of customers to shop at hypermarkets. The study aims at investigating how much differential impact these factors have on the purchase intention of customers to shop at hyper markets. Primary data were collected through survey with structured questionnaire from 150 customers in Kedah and Perlis states in Malaysia. Correlations and multiple regression analyses were employed to estimate relationships between independent and dependent variables. The results showed that brand image had the highest impact on purchase intention of customers followed by the quality of products sold at the stores and social influence. So marketers should give importance on these factors to influence customers to shop at hypermarkets.
\end{abstract}

Keywords: Purchase intention, hypermarket, social influence, socioeconomic, brand image and product quality.

\section{Introduction}

Customers' purchase intention represents their desire to buy products from a particular shop. Sometimes purchase intention is used to describe customer loyalty (Juhl et.al. 2002). And this purchase intention depends on a complex set of factors such as quality, value, and satisfaction, which can directly influence behavioral intention (Joseph et.al. 2000). Stores try to influence the buying decision process by representing their offerings in an appealing manner. In this process, there exists intense competition among grocery stores, supermarkets, discount stores, department stores, catalog showrooms; they are competing for the same customers (Kotler and Keller, 2006). Though these traditional superstores are making huge business, hypermarkets have appeared as a threat for them. These hypermarkets are gaining popularity very rapidly due to lower price and large assortments. These stores are providing more values to the customers with the use of advanced information technology, excellent logistic systems and powerful bargains (Kotler and Keller, 2006). In addition, traditional retailers are being coerced by modern stores since modern retail stores play in both the top (luxury offering) and the bottom (discount pricing) markets. Modern retailers have changed not only the structure of the retail industry, but also the pattern of consumer behavior. Nowadays, customers are facing difficulty in making their decision to select from many types of stores such as grocery stores, supermarkets, discount stores, large mega stores, and hypermarkets (Popkowski, et.al, 2004). Conventionally, customers give importance on product quality, price, responsiveness and location of the stores while making any purchasing decisions (Manish Madan and Sima Kumari, 2012, Ram, 2013). However, there are some other factors like the brand image, socioeconomic factors and social influence that have a profound influence in customers' choice (Davis, 1999). These factors are playing a significant role in the decision making process of buyers. But very few research works found where these factors have been used as the determinants of purchase intention. Only in theory, it is cited that customers' mind filter comprises of these factors. So the present study aims at investigating how much differential impact these factors have on the purchase intention of 
customers to shop at hyper markets other than the traditional determinants like, pricing policy, responsiveness, location and store environment.

\section{Literature Review}

Consumers have more options now in terms of products selection in supermarkets. For this reason, today's consumers are very much demanding and their purchasing behavior is changing over time (Besharat, 2010). They can choose from available branded products and supermarket's private brands. In advanced countries, some consumers choose to purchase supermarket's own brand due to price (Oh, 2003). In developed countries, supermarkets always try to promote their own brands along with selling others branded products (Liljander et al., 2009). In Malaysia, the consumptions of own brand have also shown significantly increasing since 2009 (Ganesah, 2010). Based on past studies on branded products, the factors of perceived price (Veale \& Quester, 2009), quality (Banovic et al., 2010), confidence (Anchor \& Kourilova, 2009), social influence (Kulviwat et al., 2009), and brand image (Chowdhury \& Andaleeh, 2007) are proven predictors for purchase intention. Responsiveness is also an important factor affecting purchase intention of customers. Customers expect the stores to understand their needs and address them in a timely manner with the availability of necessary items all the time. It is found to be a significant determinant of customer satisfaction of retail stores. (Conway and Andalib,2006).The pricing policy of retail chain stores can also greatly influence customers because price has the capability of attracting or repelling them (Monroe, K.B. Grewal, D., and Krishnan, R, 1989), especially since price functions as an indicator of quality (Lewis and Shoemaker, 1997). If the price is high, customers are likely to expect high quality, or it can induce a sense of being "ripped off, (Conway \& Andaleeb, 2006)". Pricing plays an important role in forming consumers' perception regarding products and services. (Ramirez \& Goldsmith, 2009). According to Veale et al. (2009), information and details about the product cost, transaction cost and its accessibility through mass media influence consumers' evaluations and reactions to price. Most experts think that price is an indication of quality. (Chandrashkaran \& Grewal, 2006, Roberta \& Quester, 2009). As there are many studies on the traditional factors that affect customers' buying decisions, the present study only focuses on brand image, social influence, socioeconomic and the quality of products sold at hypermarkets. These factors have been chosen on this study as the factors are mostly unaddressed in hypermarkets situation. In this study, we proceed to explore using these factors to elicit purchase intention of customers of hypermarkets. So a brief description of these factors have been given below.

\subsection{Product Quality}

An important factor constituting customer satisfaction is the quality of goods and services sold at the stores. Quality is the capacity of a product to satisfy some specific wants of the customers. Perceived quality refers to consumer's evaluation of products or brands that meet an individual's expectations. Such evaluation by individuals is their experience between two firms' brands products. According to Chowdhury \& Andaleen (2007), product quality enhances competitive advantage. In comparison between national and private brands, consumers tend to favor national brands because they are more familiar, reputable and better coverage on media (Besharat, 2010; Chen et al., 2007). Quality of products is normally measured by product features, benefits and ability to satisfy required needs and so on. It is considered to be one of the important determinants of purchase intention of customers (Gilmore, 1974). So it can be hypothesized that;

H1: Product quality positively and significantly influences purchase intention of customers to shop at hypermarkets.

\subsection{Brand Image}

The brand image means the way people view a given company or product. Hsieh \& Liljander (2009) defined brand image as the mental perception based on its associations toward a brand. Organizations try to create a strong brand that people recognize with a given product. In addition to desiring to create brand recognition in general, most companies also want their product or company to have a specific image or to be looked upon in a certain way. So brand image is the overall impression in consumers' mind that is formed from all forms of interactions with the organization. This brand image can outline how they release a product, the type of product they released, the type of advertising they do, and the type of customers they serve. The origin of product such as country produced and manufacturer affect consumers' brand image perception (Koubaa, 2007). This suggests that the process of recalling is prior experience on the company, brand reputation and product attributes that may exert some influences on consumers' reaction and purchasing behavior (Chowdhury \& Andaleeh, 2007). Positive brand image exceeds customers' expectations. Positive brand image increases the goodwill and brand value of an organization (MSG, 2014). So, we can hypothesize that 
H3: There is a positive and significant relationship between brand image and purchase intention of customers of hypermarkets.

\subsection{Socioeconomics}

Socioeconomic condition is a vital issue for the customers to make any purchase decision. One of the important factors of socioeconomics is the income of individuals; it divides people into social standing by estimating their amount and source of revenue (Schiffman, and Kanuk, 2000). Poor customers tend to purchase from low price stores and buy little from supermarkets because of their limited resources (Figuié, and P. Moustier, 2009). Customers make decisions based on their personal characteristics such as age, occupation and economic circumstances. Such factors have a direct impact on customer behavior (Kotler and Keller, 2006). This socioeconomic condition of buyers influences their purchase decisions to a great extent. For this reason, marketers consider the socioeconomic factors while designing products and promotional campaign. So we can hypothesize that

$\mathrm{H} 4$ : There is a positive and significant relationship between socioeconomic condition and purchase intention of customers to shop at hypermarkets.

\subsection{Social Influence}

Social influence refers to actions, feelings, thoughts, attitudes or behaviors of individual change through interaction with other individuals or groups. It can be seen in socialization, peer and family pressures. In social psychology, it is often related to the impact of social norms toward the changing of individual behavior and attitudes (White et al., 2009). Buying decision is related to having social values that derived from a need to be respected and to acquire desirable social status (Delre et al., 2008). It is found in some observations that most consumers do not shop alone. Peers, family members and other groups exert strong influence on the buying decision of individuals. These reference groups do the word of mouth marketing. They can play an active role in influencing the opinions of others. That influential impact sometimes goes against or in favor of the interest of a particular organization. For this reason, we hypothesized that:

$\mathrm{H} 2$ : There is a significant relationship between social influence and purchase intention of customers to shop at hypermarkets.

\section{Methodology}

For conducting the research, data were collected from both primary and secondary sources. The primary data were collected through a structured questionnaire with a likert type 5 point scale from 150 respondents who are the present customers of hypermarkets and convenience sampling was used for choosing the respondents. The secondary data were collected from publication manuals, academic journals, books and finally the current and available information from online sources. Out of the factors that influence the purchase intention of customers, the following have been taken into consideration for the present study: quality of products sold at the stores, socioeconomic condition of buyers, social influence and brand image. Survey area included two states of Malaysia which are Perlis and Kedah. Collected data were computed and analyzed by the researchers using Statistical Package for Social Sciences software. Multiple regression model was used to find out which factors significantly contributed to the purchase intention of customers to shop at hypermarkets.

\section{Demography of the Respondents}

Out of the 150 respondents, $47 \%$ were male and $53 \%$ were female. $23 \%$ were below age 30 years, $59 \%$ were between $30-40$ years and $18 \%$ were above 41 years. Among all the respondents, $65 \%$ were service holders, $23 \%$ were involved in business and remaining $12 \%$ were students and housewives.

\section{Findings Analysis}

\subsection{Reliability test of data}

The reliability of the collected data was tested using Cronbach alpha value. According to Nunally, (1978), the minimum acceptable value of Cronbach alpha is 0.7 and above. Table 1 shows that the Cronbach alpha values of all variables are 
above 0.7 that indicates good reliability of data.

Table 1: Cronbach Alpha values of all variables.

\begin{tabular}{|c|c|c|}
\hline Variable & Cronbach Alpha & No. of Items \\
\hline Product Quality & .887 & 5 \\
\hline Brand Image & .858 & 5 \\
\hline Socioeconomic & .888 & 5 \\
\hline Social Influence & .865 & 5 \\
\hline Purchase Intention & .879 & 5 \\
\hline
\end{tabular}

Table 2: Correlation Analysis Findings

\begin{tabular}{|c|c|c|c|c|c|c|c|}
\hline Variable & Mean & St. Deviation & Product Quality & Brand Image & Socioeconomic & Social Influence & Purchase Intention \\
\hline Product Quality & 3.4667 & .7702 & 1 & & & & \\
\hline Brand Image & 3.5711 & .7408 & $.557^{\star \star}$ & 1 & & & \\
\hline Socioeconomic & 3.5556 & .7816 & $.642^{\star \star}$ & $.795^{\star \star}$ & 1 & & \\
\hline Social Influence & 3.5289 & .7733 & $.598^{\star \star}$ & $.785^{\star \star}$ & $.754^{\star \star}$ & 1 & \\
\hline Purchase Intention & 3.5444 & .7743 & $.624^{\star \star}$ & $.750^{\star \star}$ & $.706^{\star \star}$ & $.737^{\star \star}$ & 1 \\
\hline
\end{tabular}

Correlation analysis was conducted to determine the degree and direction of relatedness between constructs used in the present study. As shown in the table, the degree of relatedness between independent and dependent variables are all good. It is clear from the table that the product quality, brand image, socioeconomic and social influence are positively related to purchase intention. In terms of relationship all the variables are significant.

\subsection{Regression Analysis}

Multiple-regression analysis was used with the four factors as independent variables to test the model for purchase intention (see Table 3). SPSS output shows that the independent variables such as product quality, brand image and social influence are statistically significant with positive beta values. The other independent variable, socioeconomic, was not statistically significant

The findings show that product quality is positively and significantly related to purchase intention at $5 \%$ level of significance. So hypothesis (1) is accepted. The socioeconomic condition of customers positively influences their purchase intention though it is not statistically significant at $5 \%$ level of significance. Based on the SPSS output it is found that the brand image is statistically significant at $1 \%$ significance level $(\mathrm{Sig} t=.004)$ with a positive beta. It means that brand image has significant positive effect on purchase intention. So hypothesis (2) is accepted.

Table 3: Regression Analysis Findings

\begin{tabular}{|l|c|c|c|}
\hline \multicolumn{1}{|c|}{ Independent Variables } & Beta & t value & Significant \\
\hline Product Quality & .212 & 2.476 & .014 \\
\hline Brand Image & .349 & 2.964 & .004 \\
\hline Socioeconomic & .089 & .752 & .454 \\
\hline Social Influence & .268 & 2.398 & .019 \\
\hline R-square $=.651$ & & \\
Adj R-square $=.635$ & & \\
Significant F $=0.000$ & & \\
Durbin-Watson $=2.281$ & & \\
Condition Index $=40.191$ &
\end{tabular}

Social influence is also statistically significant at $5 \%$ significance level (Sig $t=.019)$ with a positive beta. It means that social influence has significant positive effect on purchase intention. So hypothesis (4) is accepted.

The $\mathrm{R}^{2}$ was 65.6 percent meaning that the regression model used for this study can explain 65.6 percent variations on purchase intention. This indicates that there are other factors that explain the remaining 34.4 percent variations of purchase intention. The $\mathrm{F}$ value was adequate and significant at 1 percent significance level. This signifies that there was 
an adequate model. The Durbin-Watson value falls within the acceptable range which means that there was no auto correlation problem in the data. The VIF, tolerance and condition index all fall within the acceptable range and therefore there was no multicollinearity problem in the model. Normal P-P plot shows that data were linear. The histogram shows that data were normally distributed. The results suggest that model explains purchase intention of customers to shop at hypermarkets reasonably well.

\section{Conclusion}

The present study revealed insights into the factors influencing the purchase intention of customers of hypermarkets. This research gave emphasis on some factors that are overlooked in consumer researches. The research findings indicate that customers not only consider the conventional criteria like, price, product quality, location and others while taking purchase decision. The influence of their reference group and the brand image are also important to the customers for taking purchase decisions. The identification of the significant influence of product quality, social influence and brand image has confirmed the casual relationship between these factors and purchase intention proposed by Schiffman and Kanuk (2000). The study findings suggest that hypermarkets focus on product quality, brand image and social influence. The present study showed that brand image had the highest impact on purchase intention of customers followed by the quality of products sold at the stores and social influence. In spite of having some value of this research, there are some limitations of his study like data were collected from only two states of Malaysia and a small sample of 150 respondents participated in the survey that ultimately affects the representativeness of data. However, the findings have some practical implications for people involved in superstores or hypermarket business also for them who want to enter in this market. It can also provide some directions for future researches.

\section{References}

Anchor, R. J., and Kourilova, T. (2009), "Consumer perception of own brands: international differences", Journal of Consumer Marketing, Vo. 26 No. 6, pp.437-449.

Besharat, A. (2010), "How co-branding versus brand extensions drive consumers' evaluation of new products: A brand equity approach", Industrial Marketing Management, Vol. 39, Issue 8, pp. 1240-1249.

Chandrashekaran, R., and Grewal, D. (2006), "Anchoring effect of advertised reference price and sale price: The moderating role of saving presentation format", Journal of Business Research, Vol. 59, pp. 1063-1071.

Delre, A. S., Broekhizen, J. L. T., and Jager, W. (2008), "The effect of social influence on market inequalities in the motion picture industry" Advances in Complex Systems, Vol.11 No. 2, pp.273-287.

Conway Carolyn and Syed Saad Andaleeb (2006), "Customer satisfaction in the restaurant Industry: an examination of the transactionspecific model", Journal of Services Marketing, Volume 20 · Number 1 - 2006 · pp 3-11.

D. W. Wallace, J. L. Giese, and J. L. Johnson, "Customer retailer loyalty in the context of multiple channel strategies," Journal of Retailing, vol. 80, no. 4, pp. 249-263, 2004.

Ganesah, S. (2010), Shopping in-house http://thestar.com.my/lifestyle/story.asp?file=/2010/4/12/lifefocus/5957554\&sec=lifefocus (Accessed 12.04.2010).

H. Jr. Juhl, K. Kristensen, and P. stergaard, "Customer satisfaction in European food retailing," Journal of Retailing and Consumer Services, vol. 9, no. 6, pp. 327-334, 2002.

J. J. Joseph Cronin, M. K. Brandy, and G. T. M. Hult, "Assessing the Effects of Quality, Value, and Customer Satisfaction on Consumer Behavioral Intentions in Service Environments," Journal of Retailing, vol. 76, no. 2, pp.25, 2000.

Kulviwat, S., Bruner II, C. G., and Shuridah, A. O. (2009), "The role of social influence on adoption of high tech innovations: The moderating effect of public/private consumption", Journal of Business Research, Vol.62, pp.706-712.

Koubaa Y. (2007). Country of origin, brand image perception, and brand image structure", Asia Pacific Journal of Marketing and Logistics, Vol. 20 No. 2, pp.139-155.

Liljander, V., Polsa, P., Riel, V. A. (2009), "Modelling consumer responses to an apparel store brand: Store image as a risk reducer", Journal of Retailing and Consumer Services, Vol.16, pp.281-290.

Lewis, R.C. and Shoemaker, S. (1997), "Price-sensitivity measurement: a tool for the hospitality industry", Cornell Hotel and Restaurant Administration Quarterly, Vol. 38, April, pp. 44-47.

L. G. Schiffman, and L. L. Kanuk, Consumer Behavior 7th ed., Upper Saddle River, New Jersey: Prentice-Hall, Inc., 2000.

M. Figuié, and P. Moustier, "Market appeal in an emerging economy: Supermarkets and poor consumers in Vietnam," Food Policy, vol. 34, no. 2, pp. 210-217, 2009.

Manish Madan and Sima Kumari(2012), "Determinants of retail customer satisfaction: a study of organised retail outlets in Delhi," Delhi Business Review X Vol. 13, No. 1 (January - June 2012).

Monroe, K.B. Grewal, D., and Krishnan, R. (1998), "The effects of price-comparison advertising on buyers' perceptions of acquisitions value, transaction value, and behavioral intentions", Journal of Marketing, Vol. 62 No. 2, pp. 46-59. 
P. Kotler, and K. L. Keller, Marketing Management, 12th ed., Upper Saddle River: Pearson Education, Inc. 2006.

P. T. L. Popkowski Leszczyc, A. Sinha, and A. Sahgal, "The effect of multi-purpose shopping on pricing and location strategy for grocery stores," Journal of Retailing, vol. 80, no. 2, pp. 85-99, 2004.

Ram Mohan(2013), "To identify the factors impacting customer satisfaction in food retail supermarkets" International Journal of Research and Development - A Management Review (IJRDMR), ISSN (Print): 2319-5479, Volume-2, Issue - 2, 2013.

R.H. Davis (1998), "Purchase intention and its determinants", International conference on consumer research. NY, 1999.

Ramirez, E., and Goldsmith, E. R. (2009), "Some antecedents of price sensitivity", Journal of Marketing Theory and Practice, Vol.17 No. 3, pp.199-213.

Roberta, V., and Quester, P. (2009), "Do consumer expectations match experience? Predicting the influence of price and country of origin on perceptions of product quality", International Business Review, Vol.18, pp.134-144.

Veale, I., Chater, N., Lewis, R., and Davies, G. (2009), "Reasoned-based judgments: Using reasons to decouple perceived price-quality correlation", Journal of Economic Psychology, Vol.30, pp.721-731.

White, M. K., Smith, R. J., Terry, J. D., Greenslade, H. J., and McKimmie, M B. (2009), "Social influence in the theory of planned behaviour: The role of descriptive, injunctive, and in-group norms", British Journal of Social Psychology, Vol.48, pp.135-158. 